\title{
ОЦІНКА ВІДПОВІДНОСТІ СУБ'ЄКТИВНОЇ САМООЦІНКИ РІВНЯ ЗДОРОВ'Я ФАКТИЧНОМУ РІВНЮ ФІЗИЧНОГО ЗДОРОВ'Я ОБСТЕЖЕНИХ ЮНАКІВ ТА ДІВЧАТ
}

\author{
Білеиька Вікторія ${ }^{I A B C D}$, Поляничко Олена ${ }^{I C D}$, Літвінова Ксенія ${ }^{I B D}$, \\ Бірючинська Світлана ${ }^{1 B D}$, Данило Любов ${ }^{I D}$ \\ ${ }^{1}$ Київький університет імені Бориса Грінченка, Київ, Україна
}

Внесок автора: А - дизайн дослідження; В - збір даних; C - статистичний аналіз; $\mathrm{D}$ - підготовка рукопису.

\begin{abstract}
Анотація
Мета - визначення ступеня відповідності суб'єктивної самооцінки рівня здоров'я юнаків та дівчат його реальному рівню.

Матеріали. Анкетування було проведено для самооцінки рівня здоров’я (шкальована самооцінка рівня здоров'я «Градусник»). В анкетуванні взяли участь 22 учні старших класів. Експрес-оцінка здоров'я проводилася за методикою Апанасенка Г.Л. Рівень фізичної підготовленості учнів старшого шкільного віку визначали за результатами рухових тестів: «біг 60 м», «стрибок у довжину 3 місця», «підйом у сід за 30 с» та «кидок тенісного м’яча на дальність».

Результати. За результатами дослідження, самооцінка рівня фізичного здоров'я юнаків та дівчат є неадекватною - завищеною. За результатами самооцінки юнаки та дівчата мають вищий за середній рівень здоров'я; однак показник фізичного здоров'я, отриманий емпіричним шляхом відповідає посередньому рівню здоров'я - нестійкому станові, що за найменшого впливу переходить у захворювання.
\end{abstract}

Висновки. При оцінці рівня фізичного здоров’я за методикою Г.Л. Апанасенка встановлено, що 50 \% юнаків та дівчат мають середній рівень фізичного здоров'я, 27 \% - низький, по $9 \%$ - відповідно нижчий за середній та вищий за середній, і лише 5 \% - високий. За результатами дослідження, самооцінка рівня фізичного здоров'я юнаків та дівчат є неадекватною - завищеною.

Ключові слова: учні старшого шкільного віку, рівень фізичного здоров’я, суб'єктивна оцінка здоров'я.

\section{Вступ}

За даними ряду дослідників, здоров’я населення України останнім часом суттєво погіршується $[6,7,13]$. При цьому визначальним фактором, який обумовлює рівень здоров'я кожної конкретної людини, є її спосіб життя, бажано здоровий $[5,11,18]$. Водночас, чи веде людина здоровий спосіб життя, значною мірою залежить від суб'єктивних, психологічних особливостей і меншою - від наявності чи відсутності зовнішніх умов $[2,12,17]$. Об'єктивність самооцінки людиною свого здоров'я є одним із факторів, які зумовлюють формування потреби піклуватися про власне здоров'я і вести здоровий спосіб життя $[1,4]$.

Таким чином, метою нашої роботи є: визначення ступеня відповідності суб'єктивної само- оцінки рівня здоров'я юнаків та дівчат його реальному рівню.

\section{Методи}

Методи дослідження: теоретичний аналіз і узагальнення даних спеціальної літератури; соціологічні методи (анкетування); метод визначення рівня фізичного здоров'я;педагогічні методи (педагогічне спостереження та тестування); методи статистичної обробки даних.

Анкетування було проведено для самооцінки рівня здоров'я. В анкетуванні взяли участь 22 учні старших класів. «Градусник» - шкальована самооцінка рівня здоров'я. Школярам було запропоновано лінії, які відображали континуум стану здоров'я від абсолютно поганого до ідеального здоров'я, на яких вони мали по- 
значити: найгіршийстан здоров'я, який у нього (неї) траплявся; найкращий стан здоров'я, який у нього(неї) траплявся; стан здоров'я на даний конкретний момент, як він (а) його суб'єктивно оцінюе.

Експрес-оцінка здоров'я за методикою Апанасенка Г.Л. [19]. Для визначення рівня фізичного здоров'я нами вимірювалися: зріст, вага, ЖЕЛ, сила кисті руки, ЧСС у спокої, артеріальний тиск у спокої та час відновлення ЧСС після виконання 20 присідань за 30 с. У подальшому розраховувалися наступні показники, які складають профіль здоров'я:

1. Масо-ростовий індекс Кетле - співвідношення маси до зросту(зріст/ вага), вимірюється в гр /см;

2. Життєвий індекс - співвідношення життєвої ємності легень до маси тіла (ЖЄЛ / вага) (мл / кг);

3. Силовий індекс - сила кисті руки (кг) / вага тіла (кг) ' $100 \%$;

4. Індекс Робінсона - ЧСС*АД/100;

5. Час відновлення ЧСС після 20 присідань за 30 с (хв).

Відповідно до суми балів за вище вказаними показниками, учнів розподілили за рівнями фізичного здоров'я: низький, нижче середнього, середній, вище середнього, високий. Оцінка рівня фізичного здоров'я: низький рівень -4 i менше балів, нижче середнього - 5-9 балів, середній - 10-13 балів, вище середнього - 14-16 балів, високий - 17 і більше балів.

Рівень фізичної підготовленості учнів старшого шкільного віку визначали за результатами рухових тестів: «біг 60 м», «стрибок у довжину
3 місця», «підйом у сід за 30 с» та «кидок тенісного м'яча на дальність».

\section{Результати та обговорення}

Успішність оздоровлення людини значною мірою залежить від розуміння сутності здоров'я, чинників і процесів, які формують цей стан. Конкретизація сутності індивідуального здоров'я дозволить розв'язати питання про шляхи та можливості оздоровлення людини $[6,18]$.

Здоров'я не дається на все життя, не є постійним і незмінним - воно потребує постійної уваги. У живому організмі безперервно відбуваються синтез і розпад речовин, атомний склад нашого тіла постійно оновлюється.. Ці процеси, перебуваючи у стані відносної рівноваги, забезпечують життєві функції та відновлення енергетичних і структурних ресурсів організму. Подразники зовнішнього і внутрішнього середовища можуть посилювати чи гальмувати певні процеси життєдіяльності, зумовлюючи зміну рівноваги між ними [3, 14].

За результатами анкетування найгірший стан здоров'я, який траплявся у обстежених учнів старшого шкільного віку, відповідав середньому рівню у $41 \%$, низькому рівню - у $41 \%$, високому рівню - у $18 \%$ обстежених учнів. За результатами анкетування найкращий стан здоров'я, який траплявся у обстежених учнів старшого шкільного віку, відповідав середньому рівню у $14 \%$, низькому рівню - у $4 \%$, високому рівню - у $82 \%$ обстежених учнів. За результатами анкетування теперішній стан здоров'я учнів старшого шкільного віку, відповідав середньому рівню у $18 \%$, високому рівню - у $82 \%$ обстежених учнів (рис. 1).

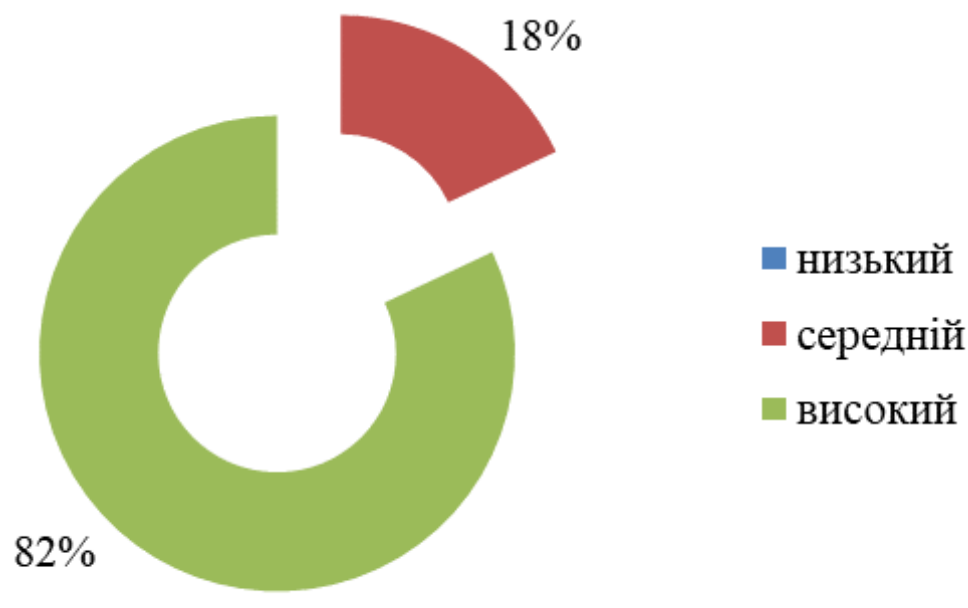

Рис. 1. Суб’єктивна оцінка теперішнього стану здоров’я у обстежених учнів старшого шкільного віку (за результатами анкетування, $\mathrm{n}=22$ ) 
Оцінку рівня фізичного здоров'я здійснювали за методикою Апанасенка Г.Л. Для визначення рівня фізичного здоров'я нами вимірювалися: зріст, вагу, ЖЕЛ, сила кисті руки, ЧСС у спокої, артеріальний тиск у спокої та час відновлення ЧСС після виконання 20 присідань за 30 с.

У подальшому розраховувалися наступні показники, які складають профіль здоров'я:масо-ростовий індекс Кетле, життєвий індекс, силовий індекс, індекс Робінсона, час відновлення ЧСС після 20присіданьза 30с.

Так, за результатами дослідження, низький рівень фізичного здоров'я мали 27 \% юнаків та дівчат, нижче середнього - $9 \%$, середній - $50 \%$, вище середнього - $9 \%$ та високий - $5 \%$.

Рівень фізичної підготовленості учнів старшого шкільного віку визначали за результатами рухових тестів: «біг 60 м», «стрибок у довжину 3 місця», «підйом у сід за 30 с» та «кидок тенісного м'яча на дальність».

Результати педагогічного експерименту виявили загалом низький рівень фізичної підготовленості: низький рівень спостерігався у $28 \%$ учнів, нижче середнього - у $23 \%$, середній у $41 \%$, вище середнього - у $4 \%$ та високий у 4 \% обстежених (рис. 2).

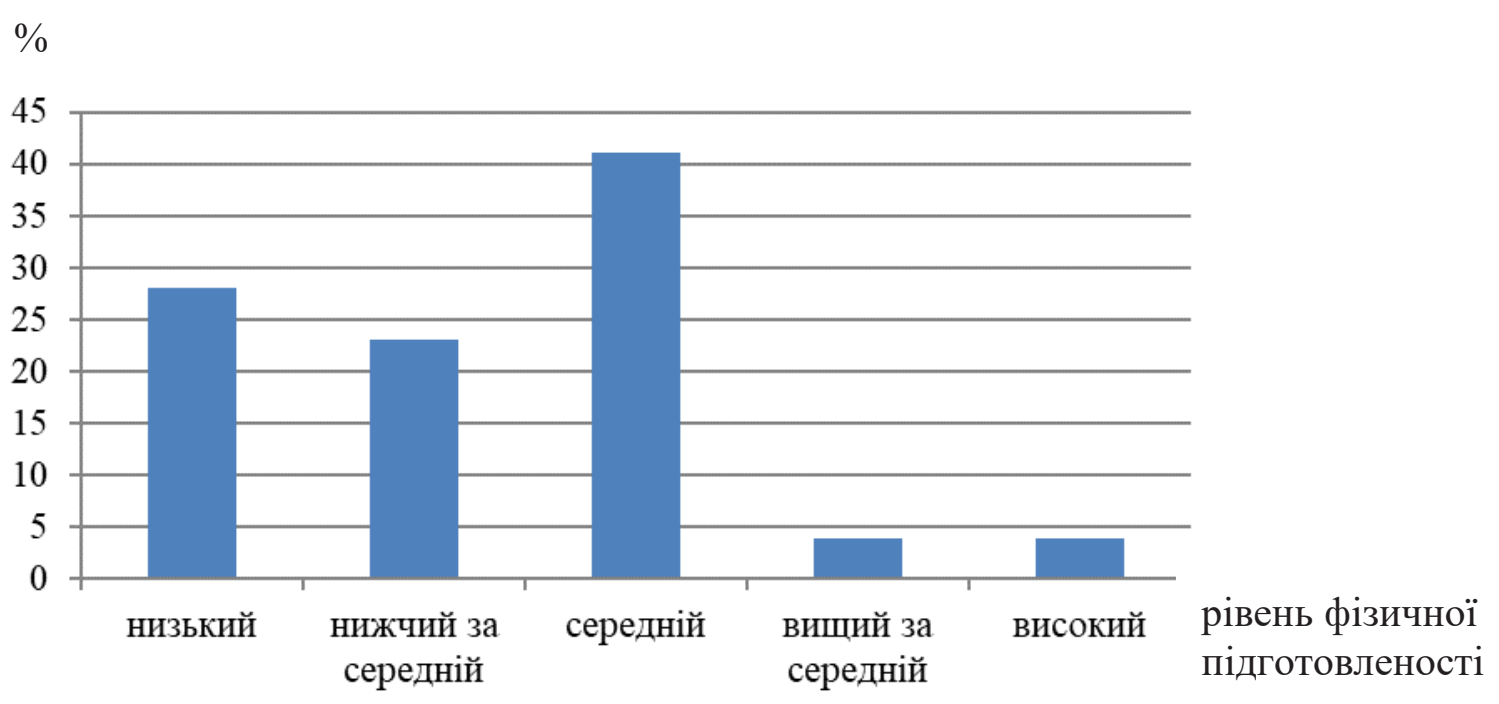

Рис. 2. Рівень фізичної підготовленості обстежених учнів старших класів (за результатами тестування, $n=22$ )

Таким чином, за результатами обстежень та тестування виявлено, що більшість юнаків та дівчат мають середній рівень фізичної підготовленості та середній рівень фізичного стану.

Рухова активність людини неможлива без прояву певного набору рухових якостей. Оcновними 3 них $є$ силові здібності. Без прояву м'язової сили жодної фізичної вправи виконати неможливо. Їх поєднання і умови прояву визначають успіх як окремого руху, так і всієї рухової діяльності в цілому. Методично правильно побудована дія на процес формування цих здібностей $є$ важливою умовою для забезпечення життєдіяльності і досягнення високих результатів в різних формах рухової активності людини i, зокрема, в спорті $[8,16,20]$.

Проблема вивчення та контролю силових показників людини - не нова, однак, з роками вона не втрачає своєї актуальності. Це пояснюється тим, що і енергетичний фонд, і функціональний стан органів та систем організму залежать від особливостей функціонування скелетної мускулатури. Швидше розвиваються м'язи, що беруть участь в зусиллях рухового апарату, пов'язаних перш за все з підтримкою вертикального положення тіла [15].

Силовий індекс показує рівень сили згиначів кисті в залежності від маси. Результати самооцінки показали, що учні старшого шкільного віку суб'єктивно оцінюють свій рівень розвитку сили наступним чином: низький - $4 \%$, нижче середнього - $0 \%$, середній - $50 \%$, вищий за середній $32 \%$, високий $-14 \%$. Натомість визначення рівня розвитку сили за силовим індексом свідчить про те, що більшість учнів 64\% має низький показник силового індексу, 14 \% - нижчий за середній, по $9 \%$ - відповідно середній і високий і лише $4 \%$ вищий за середній рівень (рис. 3). 


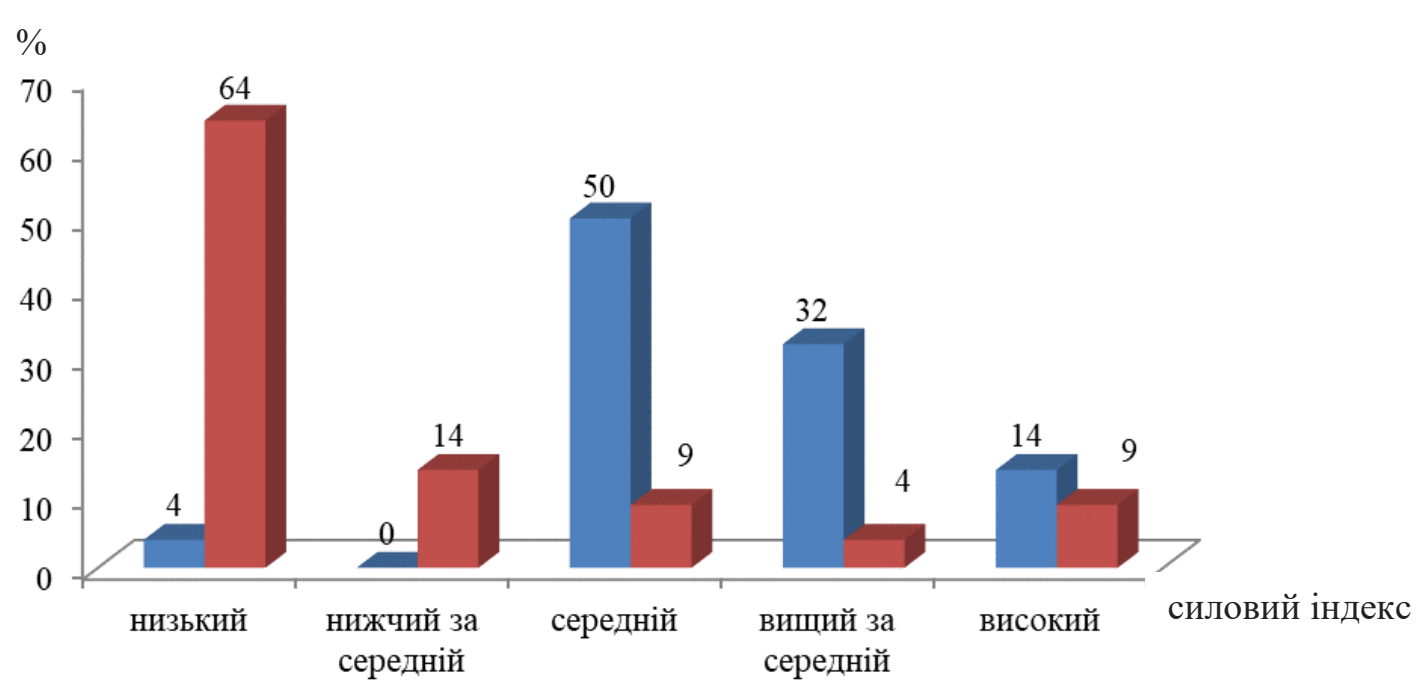

ш за результатами анкетування (самооцінка) за значенням силового індексу

Рис. 3. Порівняльна характеристика суб'єктивної (самооцінка за результатами анкетування) та об'єктивної (за розрахунком силового індексу) оцінки рівня розвитку сили у обстежених учнів старшого шкільного віку $(\mathrm{n}=22)$

За результати самооцінки визначено, що учні старшого шкільного віку суб'єктивно оцінюють свій стан дихальної системи наступним чином: низький $-4 \%$, нижче середнього - $9 \%$, середній - $33 \%$, вищий за середній - $36 \%$, ви- сокий - 18 \%. Натомість при оцінці життєвого індексу нами були отримані наступні результати: низький рівень мали $45 \%$ учнів, по $14 \%$ нижчий за середній та високий, $23 \%$ - середній та 4 \% - вищий за середній (рис. 4).

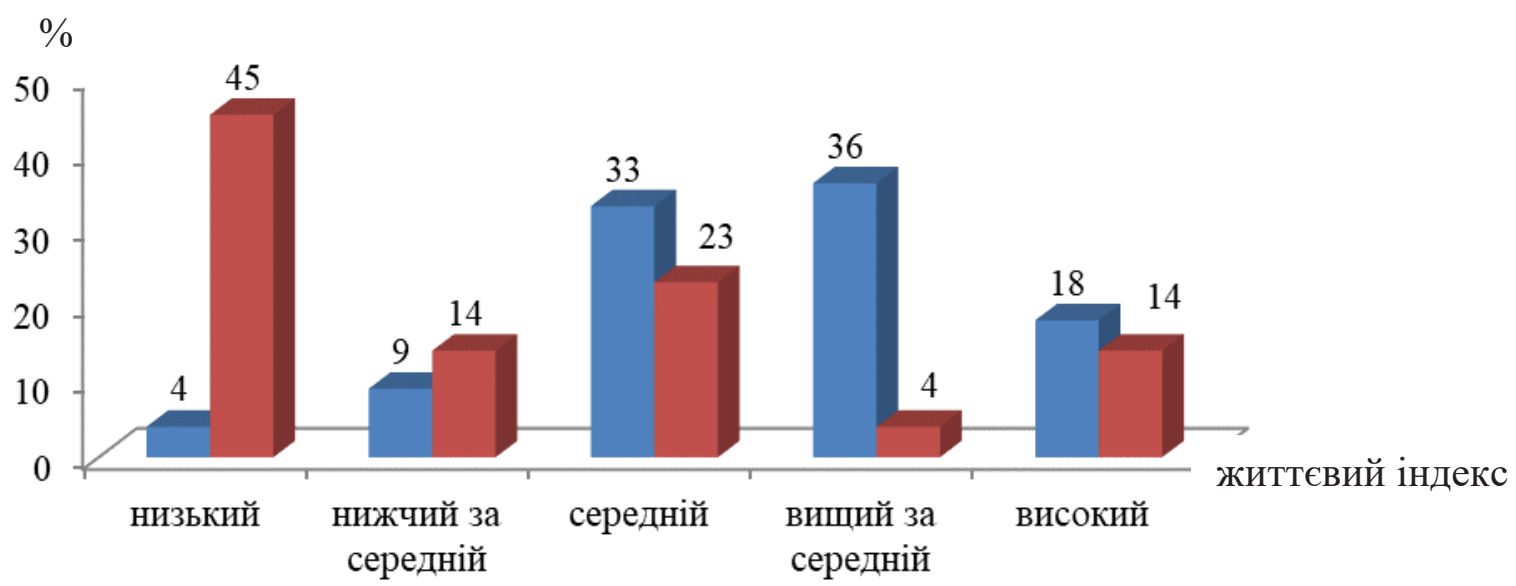

ш за результатми анкетування (самоццінка) — за значеннями життєвого індексу

Рис. 4. Порівняльна характеристика суб'єктивної (самооцінка за результатами анкетування) та об'єктивної (за значенням життєвого індексу) оцінки стану дихальної системи у обстежених учнів старшого шкільного віку $(\mathrm{n}=22)$

Показники індексу Робінсона свідчать про стан серцево-судинної системи і рухову активність юнаків та дівчат. За результати анкетування визначено, що учні старшого шкільного віку суб'єктивно оцінюють свій стан серцево-судинної системи наступним чином: низький $-0 \%$, нижче середнього - $4 \%$, середній - $14 \%$, ви- щий за середній - $23 \%$, високий - 59 \%. Однак за значеннями індексу Робінсона ми отримали наступні дані: низький рівень функціонування серцево-судинної системи притаманний 51\% школярів, нижчий за середній та середній - відповідно $18 \%$ обстежених, вищий за середній $9 \%$, високий $-4 \%$ (рис. 5 ). 


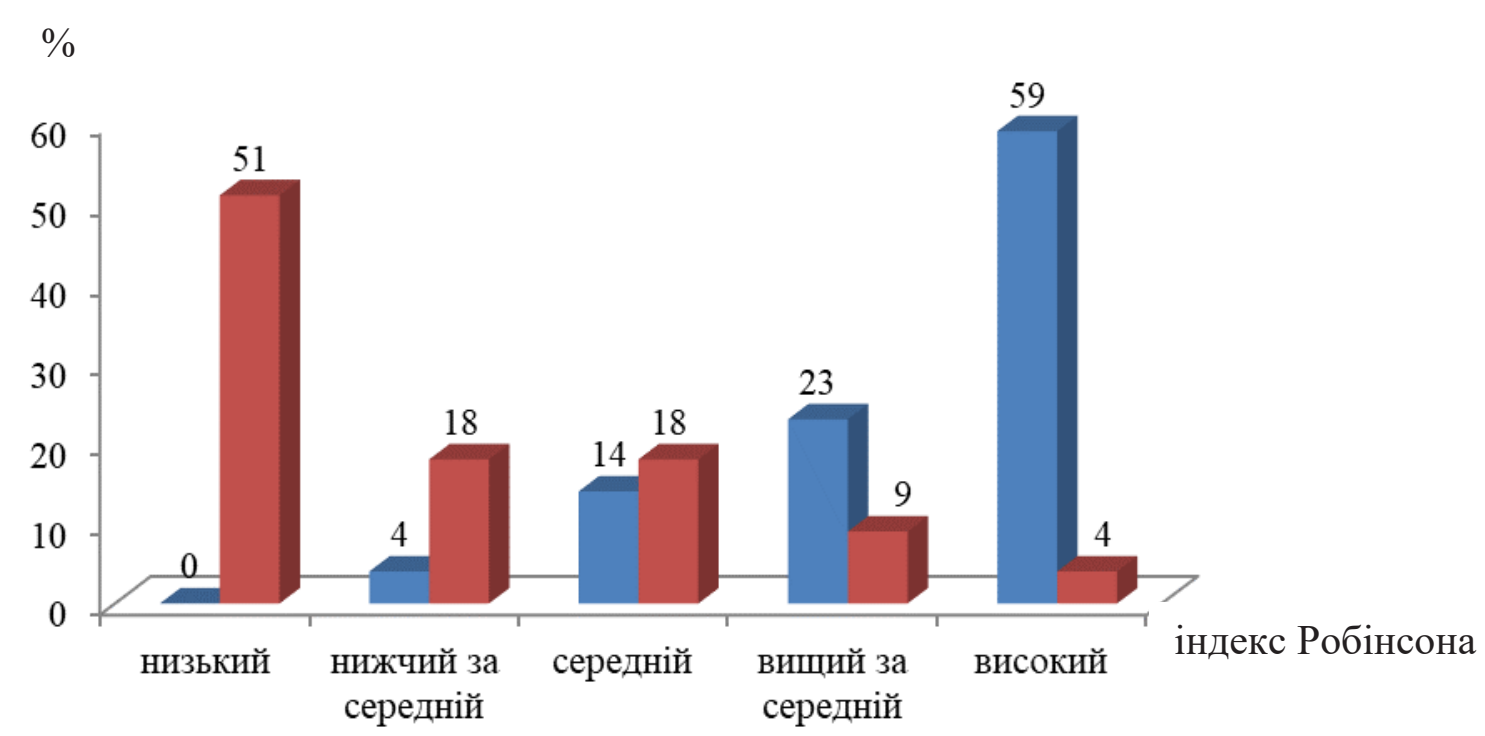

ш за результатами анкетування (самооцінка) за значеннями індексу Робінсона

Рис. 5. Порівняльна характеристика суб'єктивної (самооцінка за результатами анкетування) та об'єктивної (за значенням індексу Робінсона) оцінки стану серцево-судинної системи у обстежених учнів старшого шкільного віку $(\mathrm{n}=22)$

Фізичне (соматичне) здоров'я відображає поточний стан органів і систем органів людського організму; рівень їх розвитку і функціональних можливостей, ступінь адаптації до різних факторів зовнішнього середовища. Воно являє основу пірамідальної системи структурної організації людини. Фізичне здоров'я - це стан організму, при якому показники основних фізіологічних систем лежать в межах фізіологічної норми і адекватно змінюються при взаємодії людини з зовнішнім середовищем $[18,19]$. Ос- нову фізичного здоров’я становить біологічна програма індивідуального розвитку людини, яка опосередкована базовими потребами (харчування, дихання, рух, пізнання навколишнього світу, сексуальне задоволення і т.д.), домінуючими у нього на різних етапах $[9,10]$.

Результати анкетування свідчать, учні старшого шкільного віку суб'єктивно оцінюють свій рівень фізичного здоров'я наступним чином: середній $-41 \%$, вищий за середній $-41 \%$, високий $-18 \%$ (рис. 6).

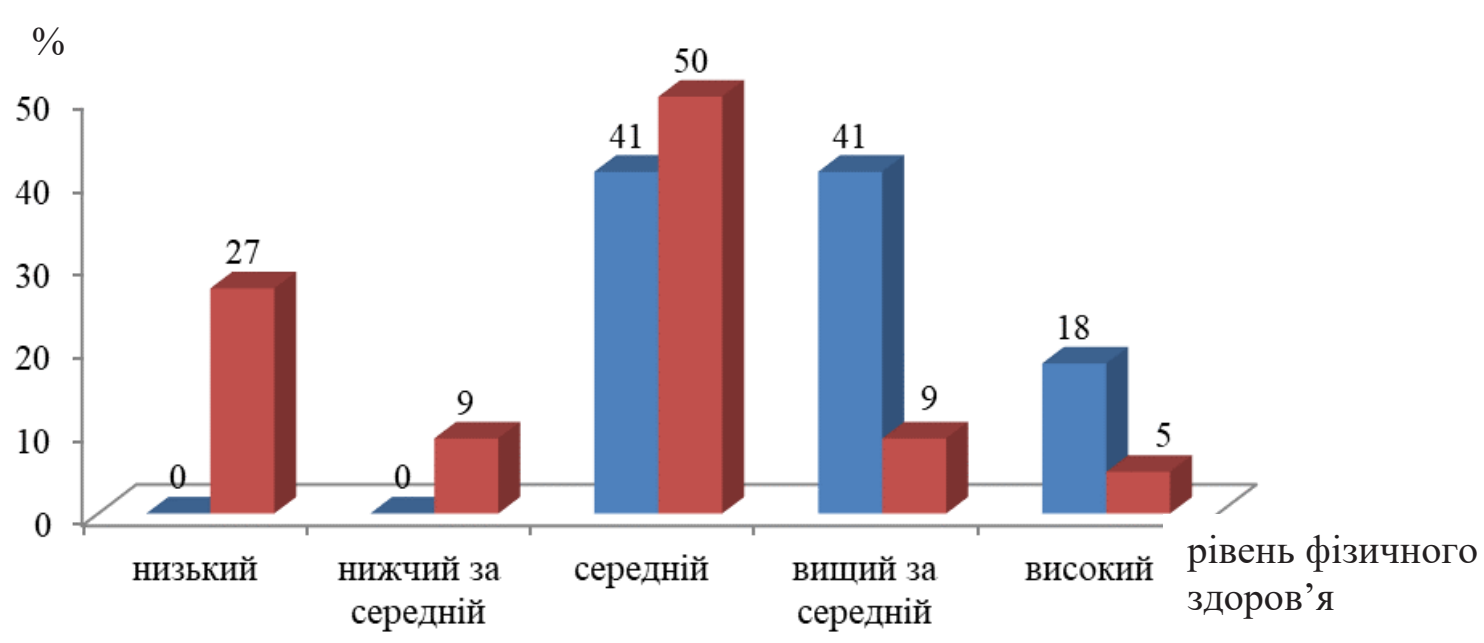

ш за результатами анкетування (самооцінка) च за методикою Апанасенка Г.Л.

Рис. 6. Порівняльна характеристика суб'єктивної (самооцінка за результатами анкетування) та об’єктивної (за методикою Апанасенка Г.Л.) оцінки рівня фізичного здоров’я у обстежених учнів старшого шкільного віку $(\mathrm{n}=22)$ 
При цьому ніхто зі школярів не оцінив свій рівень фізичного стану як низький та нижче середнього. Але при оцінці рівня фізичного здоров'я за методикою Г.Л. Апанасенка було встановлено, що 50 \% юнаків та дівчат мають середній рівень фізичного здоров'я, $27 \%$ - низький, по $9 \%$ - відповідно нижчий за середній та вищий за середній, 5 \% - високий.

Нами підтверджено результати дослідження авторів $[3,8,9]$, що в більшості випадків українська молодь має низький та нижчий за середній рівень фізичного здоров'я, низький рівень функціонування серцево-судинної системи та дихальної системи. Також доповнено дані $[1,9,13]$ про кількісні показники серцево-судинної та дихальної системи юнаків та дівчат, а також про рівень фізичної підготовленості сучасної молоді.

\section{Висновки}

Результати анкетування свідчать, учні старшого шкільного віку суб'єктивно оцінюють свій рівень фізичного здоров'я як середній та вищий за середній - відповідно по 41 \% школярів. При цьому ніхто зі школярів не оцінив свій рівень фізичного здоров'я як низький та нижче середнього. Але при оцінці рівня фізичного здоров'я за методикою Г.Л. Апанасенка було встановлено, що 50 \% юнаків та дівчат мають середній рівень фізичного здоров'я, $27 \%$ - низький, по $9 \%$ - відповідно нижчий за середній та вищий за середній, і лише $5 \%$ високий. За результатами дослідження, самооцінка рівня фізичного здоров'я юнаків та дівчат $\epsilon$ неадекватною - завищеною. За результатами самооцінки юнаки та дівчата мають вищий за середній рівень здоров'я; однак показник фізичного здоров'я, отриманий емпіричним шляхом відповідає посередньому рівню здоров'я нестійкому станові, що за найменшого впливу переходить у захворювання.

\section{Конфлікт інтересів}

Автори заявляють про відсутність конфлікту інтересів.

\section{References}

1. Andreeva OV. Theoretical and methodological principles of recreational activity of different population groups [dissertation]. Kyiv; 2014. 400 p.

Андрєєва ОВ. Теоретико-методологічні засади рекреаційної діяльності різних груп населення [дисертація]. Київ; 2014. 400 с.

2. Bezverkhnya GV, Mayevsky MI. Motivation for physical education of female students of pedagogical specialties. Slobozhans 'ky`j naukovosporty'vny’j visny'k. 2015; 2: 28-33.

Безверхня ГВ, Маєвський МІ. Мотивація до занять фізичним вихованням студенток педагогічних спеціальностей. Слобожанський науково-спортивний вісник. 2015; 2: 28-33.

3. Biletska VV, Semenenko VP, Trachuk SV. Characteristics of the functional state of the cardiovascular system of young school children with different levels of physical health. Naukovy'j chasopy`s Nacional'nogo pedagogichnogo universy'tetu imeni M.P.Dragomanova. 2016; 01 (68) 16: 18-21. Білецька ВВ, Семененко ВП, Трачук СВ. Характеристика функціонального стану серцево-судинної системи дітей молодшого шкільного віку з різним рівнем фізичного здоров'я. Науковий часопис Національного педагогічного університету імені М.П.Драгоманова. 2016; 01 (68) 16: 18-21.

4. Dutchak MV. The paradigm of wellness motor activity: theoretical grounding and practical applica- tion. Teoriya i metody 'ka fizy ‘chnogo vy`xovannya i sportu. 2015; 2: 44-52.

Дутчак МВ. Парадигма оздоровчої рухової активності: теоретичне обгрунтування і практичне застосування. Теорія і методика фізичного виховання і спорту. 2015; 2: С. 44-52.

5. Futorny S, Shkrebtiy Y. Formation of healthy lifestyle of young generation in the process of physical education. Teoriya i metody`ka fizy`chnogo vy`xovannya i sportu. 2016; 2: 54-57.

Футорний С, Шкребтій Ю. Формування здорового способу життя молодого покоління у процесі фізичного виховання. Теорія і методика фізичного виховання і спорту. 2016; 2: 54-57.

6. Global Strategy for Nutrition, Physical Activity and Health 2017 [Online resource]. According to the World Health Organization. URL: http: //www. webcitation.org/6538BcQgf.

Глобальна стратегія 3 харчування, фізичної активності та здоров'я 2017 [Електронний ресурс]. За даними Всесвітньої організації охорони здоров'я. URL: http: //www.webcitation. org $/ 6538 \mathrm{BcQgf}$.

7. Gryban G, Romanchuk S, Romanchuk V, Boyarchuk O, Gusak O. Physical preparation of students in Ukraine. American Journal of Scientific and Educational Research. 2014; 1(4): 286-291.

8. Kateryna U. Analysis of theoretical preparedness of students of higher educational institutions in 
physical education. Fizy'chna kul'tura, sport ta zdorov'ya naciyi. 2014; 18 (1): 92-98.

Катерина У. Аналіз теоретичної підготовленості студентів вищих навчальних закладів 3 фізичного виховання. Фізична культура, спорт та здоров'я нації. 2014; 18 (1): 92-98.

9. Kensitska I. Characteristics of indicators of physical condition of student youth. Naukovy ‘ $j$ chasopy`s NPU imeni M.P. Dragomanova. 2017: 46-50.

Кенсицька I. Характеристика показників фізичного стану студентської молоді. Науковий часопис НПУ імені М.П. Драгоманова. 2017: 46-50.

10. Moskalenko N, Korzh N. Technology of formation of value attitude in students to independent employment by physical culture. Sporty 'vny`j visny’k Pry`dniprov’ya. 2016; 1: 201-206.

Москаленко Н, Корж Н. Технологія формування ціннісного ставлення у студентів до самостійних занять фізичною культурою. Спортивний вісник Придніпров'я. 2016; 1: 201-206.

11. National Strategy for Wellness Movement Activity in Ukraine for the Period up to 2025 "Movement Activity - Healthy Lifestyle - Healthy Nation". URL: http://zakon0.rada.gov.ua/laws/show/42/20160.

Національна стратегія 3 оздоровчої рухової активності в Україні на період до 2025 року «Рухова активність - здоровий спосіб життя - здорова нація». URL: http://zakon0.rada.gov.ua/laws/ show/42/20160.

12. Pavlova I,Vynogradskyi B, Ripak I. Prognostication of health-related life quality of Ukrainian residents due to physical activity level. Journal of Physical Education and Sport. 2016; 16(2): 418-423.

13. Sadovsky OO. Formation of recreational culture of student youth in the process of physical education [avtoreferat]. Kyiv; 2017. 20 p.

Садовський ОО. Формування рекреаційної культури студентської молоді в процесі фізичного виховання. [автореферат]. Київ; 2017. 20 с.

14. Shyyan O, Nakonechnyi Y. Cooperation for Health Promotion. Modern world: Science and Education. 2015; 2: 325-330.
15. Stolyarov VI. The theory and methodology of modern physical education: the state of development and the author's concept. Kiev; 2015. 704 p.

Столяров ВИ. Теория и методология современного физического воспитания: состояние разработки и авторская концепция: монография. Київ; 2015. 704 с.

16. The concept of national patriotic upbringing of children and young people for 2016-2020. URL: http://pnpu.edu.ua/en/files/vr/strategy.pdf.

Концепція національно-патріотичного виховання дітей та молоді на 2016-2020 роки. URL: http://pnpu.edu.ua/ua/files/vr/strategy.pdf

17. Tomenko OA. Non-specific physical education of student youth: theory and methodology. Sumy; 2012. $276 \mathrm{p}$.

Томенко ОА. Неспеціальна фізкультурна освіта учнівської молоді: теорія і методологія. Суми; 2012. $276 \mathrm{c}$.

18. Vakulenko OV. Modern aspects of healthy lifestyle formation in Ukraine and the world. Naukovy 'j chasopy`s Nacional'nogo pedagogichnogo universy'tetu imeni M.P. Dragomanova. 2016; 21(11) : 114-121.

Вакуленко О. В. Сучасні аспекти формування здорового способу життя в Україні та світі. Науковий часопис Національного педагогічного університету імені М.П. Драгоманова. 2016; 21 (11): 114-121.

19. Zinchenko VB, Biletska VV, Yasko LV. Physical Education. Methods of self-control of a physical condition: a workshop for students of all directions of preparation. Kyiv: NAU; 2015. 48 p.

Зінченко ВБ, Білецька ВВ, Ясько ЛВ. Фізичне виховання. Методи самоконтролю фізичного стану: практикум для студентів усіх напрямів підготовки. Київ: НАУ; 2015. 48 с.

20. Zinchenko VB, Usachev YO, Biletska VV, Semenenko VP. Physical Education. Fitness. Kyiv; 2014. $220 \mathrm{p}$.

Зінченко ВБ, Усачов ЮО, Білецька ВВ, Семенен ко ВП. Фізичне виховання. Фітнес. Київ; 2014. $220 \mathrm{c}$.

\section{Інформація про авторів:}

\section{Білецька Вікторія}

https://orcid.org/0000-0002-8813-1747

Київський університет імені Бориса Грінченка, Київ, Україна

v.biletska@kubg.edu.ua

\section{Поляничко Олена}

http://orcid.org/ 0000-0002-4775-6732

Київський університет імені Бориса Грінченка, Київ, Україна

o.polianychko@kubg.edu.ua 


\section{Літвінова Ксенія}

https://orcid.org/0000-0003-0823-8032

Київський університет імені Бориса Грінченка, Київ, Україна

k.litvinova@kubg.edu.ua

\section{Бірючинська Світлана}

https://orcid.org/0000-0002-6627-2418

Київський університет імені Бориса Грінченка, Київ, Україна

s.biriuchinska@kubg.edu.ua

\section{Данило Любов}

https://orcid.org/0000-0001-7083-8237

Київський університет імені Бориса Грінченка, Київ, Україна

1.danylo@kubg.edu.ua

Отримано: 12.06.2019;

Прийнято 24.06.2019; Опубліковано: 28.06.2019. 